\title{
Research on Management Innovation of Sino-foreign Cooperation in Running School under the Background of "the Belt and Road" Strategy*
}

\author{
Hao Feng \\ School of Humanities and Law \\ Northeastern University \\ Shenyang, China 110819 \\ School of Humanities and Law \\ Shenyang University \\ Shenyang, China 110041
}

\author{
Wanbing Shi \\ School of Humanities and Law \\ Northeastern University \\ Shenyang, China 110819
}

\begin{abstract}
It has great significance on social development in our country to research management innovation of Sinoforeign cooperative education under the background of "the Belt and Road". After defining the strategic connotations of "the Belt and Road" and Sino-foreign cooperation in running school, this paper discusses the opportunities and challenges and acceleration brought by "the Belt and Road" strategy for Sino-foreign cooperation in running school, and analyses the current situation of Sino-foreign cooperation in running school and its unconformity to the strategy, and then it proposes the innovative suggestions and measures for management of Sinoforeign cooperation in running school under the background of "the Belt and Road" strategy, so as to improve the management and realize the sustainable and benign development of Sino-foreign cooperation in running school, and make the higher education better serve "the Belt and Road" development strategy and prosper economy and society.
\end{abstract}

Keywords-“The Belt and Road" strategy; Sino-foreign cooperation in running school; current status analysis; management innovation; suggestions

\section{INTRODUCTION}

In the promotion of education internationalization, "the Belt and Road" has higher requirements for Sino-foreign cooperation in running school. The implementation of "the Belt and Road" strategy requires numerous talents. Management measures of Sino-foreign cooperation in running school should be innovated to integrate in community of higher education. The exchange of education, technology and management with countries and universities around "the Belt and Road" to continuously improve quality and efficiency of Sino-foreign cooperation in running school must be strengthened.
*Fund project: Research result of national social science foundation project (BFA150043)

\section{DEFINITION OF CORE CONCEPTS}

\section{A. "The Belt and Road" Strategy}

When visiting four countries in Central Asia in September 2013, President Xi Jinping proposed at Nazarbayev University in Kazakhstan that "In order to realize closer economic relation, deeper cooperation and broader development space, we can use innovative cooperation model to construct 'Silk Road Economic Belt'"، [1] On October 3, 2013, when attending the APEC Leaders' Meeting, President Xi Jinping made a speech of Join Hands to Construct China-ASEAN Community of Common Destiny, in order to strengthen the maritime cooperation with ASEAN countries and jointly construct the initiative of "the $21 \mathrm{st}$ Century Maritime Silk Road". [2] The Third Plenary Session of the 18th Central Committee of the CPC upgrades it to national strategy. According to "the Belt and Road" plan, establish Silk Road Investment Bank and Fund to give financial support; sign agreement with foreign partners and invest 40 billion US dollars to establish Silk Road Fund, contribute 100 billion yuan under initiative of China to establish Asian Infrastructure Investment Bank (AIIB). At present, more than 50 countries and areas have applied to join, forming "AIIB Fever". [3]

\section{B. Sino-Foreign Cooperation in Running School}

Sino-foreign cooperation in running school is also called international cooperative cooperation in Running Schools. Article 2 of Chapter 1 in Regulations of the People's Republic of China on Chinese-Foreign Cooperation in Running Schools promulgated by the State Council on March 1, 2003 stipulates: Chinese-foreign cooperatively-run schools refer to foreign educational institutions and Chinese educational institutions cooperate in establishing educational institutions within the territory of China to provide education service mainly to Chinese citizens" [4], treating the rising of neo-liberalism thought represented by education from the market perspective to influence the development of 
international cooperation in running schools. Neo-liberalism thinks education is the service provided by the market for customers with ability to pay. [5]

\section{OPPORTUNITIES, CHALLENGES AND ACCELERATION BROUGHT BY “THE BELT AND ROAD” STRATEGY FOR THE DEVELOPMENT OF SINO-FOREIGN COOPERATION IN RUNNING SCHOOL}

\section{A. Opportunities Brought by "The Belt and Road" Strategy}

First, platform for policy communication of countries is provided. The implementation of "the Belt and Road" strategy avails countries to communicate and negotiate policies of higher education, which is the first problem that must be solved by countries. Communication in policies makes countries formulate correct and reasonable development plan, trust and benefit mutually, settle disputes in consultation and cooperation and propose correct solutions immediately.

Second, platform for facility sharing of countries is provided. "The Belt and Road" strategy must adhere to the principle of equality and mutual benefit. Countries along the line use the platform brought by "the Belt and Road" to share educational and technological resources and communication facilities, carry out multilateral trade, promote the internationalization of education. Strengthen inspection and construction of basic design and create good environment.

Third, ways of communication of countries are provided. "The Belt and Road" provides convenient channels of educational connection for countries. The connection of overland and maritime cables strengthens the relation and avail the communication of educational information. It meets social demands through training tremendous high-end technical talents and makes the best of superior resources in countries.

\section{B. Challenges Brought by "The Belt and Road"}

First, the quality of Sino-foreign cooperation in running schools fails to meet demands of "the Belt and Road" strategy. In recent years, countries realize the significance of establishing international cooperation on guaranteeing the quality of cross-border education. Altbach addresses because the quality guarantee system of one country cannot reflect the complexity of education flow of different countries, cultures and judicial systems, making the society have confidence in higher education is of great importance for Sino-foreign cooperation in running schools. Only through cooperation can we establish common system to guarantee the quality and integrity of Sino-foreign cooperation in running schools and improve confidence of the masses. [6]

Second, internationalization level and cognitive competence of teachers in Sino-foreign cooperation in running schools fail to meet demands of "the Belt and Road" strategy. Universities involved in Sino-foreign cooperation in running schools requires teachers to teach in English or bilingually, so they must have broad international perspective and solid professional skills. At present, the teaching quality in China fails to meet demands of training international talents because teachers have weak English expression ability and fail to research national conditions at home and abroad. Although teachers in some universities are overseas returnees, under the big background of "the Belt and Road", the levels of teachers are uneven and remain to be improved. [7]

Third, the unsound quality guarantee system of Sinoforeign cooperation in running schools cannot meet demands of "the Belt and Road" construction. Because of different profit motives, the quality of Sino-foreign cooperation in running schools also has severe problems. When quantity and scale expand increasingly, although the quality guarantee system of Sino-foreign cooperation in running schools plays a role, the quality of graduates is in the middle and lower level. Currently, in order to avoid stiff competition and gain enormous economic benefits, many universities that are not prominent in their own countries run schools in China. The most important reason is that the quality guarantee system of Sino-foreign cooperation in running schools in China is unsound.

\section{Acceleration Brought by "The Belt and Road" Strategy}

First, "the Belt and Road" strategy guides public opinions on Sino-foreign cooperation in running schools. With active participation of the public and the intensification of consciousness in supervision, the supervision system of China gradually improves, especially the eagle-eyed news media, such as the nonstandard fee collection of cooperation in running schools; students cannot graduate smoothly because of unreasonable curriculum provision; schools fail to supervise strictly, so students learn nothing, the graduation certificate cannot be approved, and all efforts of students and parents are wasted. [8] Attentions of media are paid to fields related to "the Belt and Road", so it guides public opinions on Sino-foreign cooperation in running schools.

Second, "the Belt and Road" strategy can deepen objectives and level of running school. The complementation of educational resources promotes the development of countries and areas along "the Belt and Road". Chinese government emphasizes countries discuss science and technology, establish maritime cooperation center, international technology transfer center and joint laboratory (research center) with other countries; increase the number of overseas students and strengthen communication of talents through Sino-foreign cooperation in running schools; promote the cooperation in vocational skills, employment and training. China provides richer platforms and objectives for Sino-foreign cooperation in running schools.

Finally, "the Belt and Road" strategy promotes our country to provide higher education resources for surrounding countries. The Sino-foreign cooperation in running schools should be two-way. In the past, our country is always "bringing in". The implementation of "the Belt and Road" strategy turns "brining in" into "going out" and forms new pattern of Sino-foreign cooperation in running schools. It integrates domestic and foreign educational resources, taking foreign citizens as enrollment targets and carry out teaching activities. These schools must have independent 
legal entity and be approved by the government, so that they can carry out degree education, in order to form education system with Chinese characteristics. [9] "The Belt and Road" strategy advocates cross-regional cultural exchange, internationalization of talent training and academic organization, and nationalization of inter-school cooperation, in order to promote internationalization of higher education and deepen comprehensive reform of higher education and improve education quality.

\section{CURRENT SituAtion OF MANAGEMENT IN SinO- FOREIGN COOPERATION IN RUNNING SCHOOLS UNDER THE BACKGROUND OF “THE BELT AND ROAD” STRATEGY}

\section{A. Current Situation of Management in Sino-Foreign Cooperation in Running Schools}

"By March 2016, there are more than 2,400 Chineseforeign cooperatively-run schools and projects established through approval of approving authority in accordance with law. Projects and institutions that provide education of bachelor or above degree have 894 and 62 respectively. Eight institutions have corporate capacity, including Cheung Kong Graduate School of Business, Beijing Normal University-Hong Kong Baptist University United International College, and The Chinese University of Hongkong, Shenzhen, New York University Shanghai, Duke Kunshan University, Xi'an Jiaotong-Liverpool University, University of Nottingham Ningbo China, and WenzhouKean University." [10] At present, in China, the number of existing students of Sino-foreign cooperation in running schools is about 560,000; the number of graduates of Sinoforeign cooperation in running schools has exceeded $1,600,000$; the number of students enrolled annually by Chinese-foreign cooperatively-run schools and projects exceeds 100,000. It indicates the management structure of Sino-foreign cooperation in running schools still has problems, including:

First, the proportion distribution of Chinese-foreign cooperatively-run schools and projects is severely uneven. The number of Chinese-foreign cooperatively-run schools is far below that of the Chinese-foreign cooperatively-run projects; second, the arrangement of hierarchical structure of Sino-foreign cooperation in running schools is improper. Investigation indicates that the Sino-foreign cooperation in running schools only has three fourths of undergraduate level, less than one fourth of graduate level and few of doctoral level, going against the development of Sino-foreign cooperation in running schools to a great extent; third, the management structure of legal person in Chinese-foreign cooperatively-run schools is extremely unreasonable. Currently, few Chinese-foreign cooperatively-run schools have independent legal person qualification, indicating the management structure of legal person in it needs improvement; fourth, talents who study overseas outflow. The number of overseas returnees is half that of the people studying abroad; fifth, Sino-foreign cooperation in running schools fails to formulate reasonable development plan. The Outline proposes the management system of higher education "under the unified leadership of the Central
Committee of the Communist Party of China and under the dominance of its subordinate provincial governments", indicating administrative departments for education at provincial level must strengthen overall management of higher education, but not all provinces and cities are suitable for Sino-foreign cooperation in running schools. Therefore, we must propose and formulate development plan of higher education reasonably to meet social and economic development; the structural system of higher education and the objective of managers must be clear. Development directions and disciplines of schools can be proposed roundly to achieve effective cooperative development. [11]

\section{B. Unconformity of Management in Sino-Foreign Cooperation in Running Schools to "The Belt and Road" Strategy}

On one hand, the training system of international talents required by construction of "the Belt and Road" strategy needs improvement. World recognized high-level universities emphasize students' deep understanding of knowledge in teaching. Therefore, in management of Sinoforeign cooperation in running schools, recognizing teaching characteristics of high level Chinese-foreign cooperativelyrun schools. Deep learning has five teaching characteristics: First, let students gain new knowledge by reviewing old on the basis of understanding learning contents; second, let students combine learning with thinking, flexibly apply knowledge to social practice; third, let students diffuse thinking and carry out innovation and development of discipline knowledge; fourth, let students establish correct values and shape good morality; fifth, provide students with good learning resources for the convenience of knowledge expansion. [12]

On the other hand, the "going out" Sino-foreign reverse cooperation in running schools in countries along "the Belt and Road" needs further development. Promote internationalization of Chinese higher education, let highlevel Chinese educational institutions run schools abroad and strengthen international educational communication and cooperation. However, in countries along "the Belt and Road", the conditions are complicated, the political scene is turbulent, the development level of higher education is low and the areas, stratum and religious factions are complex, so Chinese universities cannot cooperate with these countries, directly leading to the absence of Sino-foreign cooperation in running schools in these countries. In reality, most Sinoforeign cooperation in running schools within the territory of China are "bringing in" instead of "going out". Therefore, we must change idea in output of education and make the best of educational resources and strengthen top-level design and the guidance of policy, as well as intensify the Sinoforeign reverse cooperation in running schools in countries along "the Belt and Road".

Last, absorb and dispatch more overseas students in countries along "the Belt and Road". Specifically, on one hand, absorb more overseas students in countries along "the Belt and Road". Meanwhile, the scale and level of overseas students must be improved to meet the demands of "the Belt and Road" construction. On the other hand, "going out" 
overseas students seldom select countries along "the Belt and Road" as destination of studying. Therefore, policies must be introduced to support students to study in countries along "the Belt and Road". More "going out" talents who understand and contribute to "the Belt and Road" construction willingly can be dispatched to countries along "the Belt and Road" through forms of Sino-foreign cooperation in running schools such as "two plus two" and "three plus one".

\section{InNOVATIVE SUGgESTIONS AND MEASURES FOR MANAGEMENT IN SINO-FOREIGN COOPERATION IN RUNNING SCHOOLS UNDER THE BACKGROUND OF "THE BELT AND ROAD" STRATEGY}

\section{A. Establish Training Objectives of International Talents Required by "The Belt and Road" Construction}

The implementation of "the Belt and Road" strategy must insist on talent priority strategy. Educational development aims at training more talents. Therefore, in Sino-foreign cooperation in running schools, universities must highlight characteristics and formulate training plan of high-level international talents who can construct "the Belt and Road", such as talents who have broad international view, understand international rules and make a difference in international affairs and competition. We can explore from the following aspects:

First, pay attention to cross-cultural research and talent training in "the Belt and Road". Countries along "the Belt and Road" have differences in historical tradition, custom, language and religion. In order to achieve goals of "the Belt and Road" strategy, the formulation of talent training plan must exploit the advantages of humanity, history and language in universities, predict cultural conflicts brought by "the Belt and Road" and countermeasures, train talents familiar with culture and history of countries along "the Belt and Road", especially talents adept at minority languages; second, value research of politics and law and talent training in "the Belt and Road". Countries along "the Belt and Road" have different political system, laws and regulations. Sinoforeign cooperation in running schools needs talents familiar with political system, laws and regulations at home and abroad, in order to settle conflict of laws; third, value international trade and financial research and talent training in "the Belt and Road". Unblocked trade and capital proposed by "the Belt and Road" propose brand new requirements for Chinese-foreign cooperatively-run schools and projects related to specialties of management, marketing, international trade and finance. These universities must optimize patterns and means of talent training and train highlevel innovative talents with experience in financial innovation, the establishment of Free Trade Zone and convenience of customs clearance. [13]

\section{B. Bring "Going-out" Sino-Foreign Cooperation in Running Schools into the Countries along "The Belt and Road" line for Great Development}

The implementation of "the Belt and Road" provides hard-won opportunities for Sino-foreign reverse cooperation in running schools through "going out". More than ten countries along "the Belt and Road" line such as Jordan, Egypt, Kazakhstan and Pakistan invite China in cooperation in running schools, in order to train urgently needed talents for "the Belt and Road" construction and talents who know China's national condition and solve problems in China and adapt to social and economic cooperation in China for countries. Therefore, management organizations of Sinoforeign cooperation in running schools should take the following measures:

First, refer to successful cases in countries such as America, Britain and Australia that output high quality educational resources to enrich domestic educational resources and optimize educational mechanism, encourage universities to establish new educational partnership with countries along "the Belt and Road", center on win-win cooperation and popularize educational projects with Chinese characteristics; second, deeply research cross-border educational laws and regulations, market of higher education, pattern and structure of educational management, support domestic educational institutions to carry out Sino-foreign reverse cooperation in running schools with foreign countries in information consultation and decision making; third, improve the Management Measures for Universities to Run Schools in Foreign Countries to regularize the conducts of overseas education output, classify and subdivide the pattern, type, border, degree awarding, approval authority and procedures; fourth, establish platforms of international cooperation. Give great impetus to Sino-foreign cooperation in running schools at higher level, international cooperation in running schools, further realize mutual visiting, exchange of students, mutual recognition of credit, scientific and technological cooperation, resource sharing, jointly carry out high level education and construction of platforms in scientific and technological cooperation, in order to meet demands for talents in development of "the Belt and Road" strategy.

\section{Enlarge the Introduction and Dispatch of Overseas Students from and into the Countries along "The Belt and Road" Line}

On one hand, introduce overseas students of the countries along "the Belt and Road" line, which is the best way to train talents for "the Belt and Road" construction and is a win-win process. More than 60 countries along "the Belt and Road" line have different politics, laws, society and culture. The most important solution is to carry out Sino-foreign cooperation in running schools, in order to realize connection of policies, communication, trade, funds and the masses. On the other hand, dispatch overseas students to countries along "the Belt and Road". We must introduce policies to encourage young people to study in South Asia and Central Asia, and train professional and technical talents for "the Belt and Road" construction. Chinese universities are suggested to take the following measures to dispatch more overseas students to countries along "the Belt and Road" line: 


\section{Guarantee Teaching Quality of Sino-Foreign Cooperation in Running Schools}

In Sino-foreign cooperation in running schools, Chinese partners must strengthen ability building and play a key role. First, understand connotation of Sino-foreign cooperation in running schools, and confirm mission and objectives in running schools and grasp differences between China and foreign countries, and then play a dominant role in decision making in board of directors, management institutions and create good educational environment and provide teaching resources, in order to guarantee the stable and sound development of Sino-foreign cooperation in running schools. [14] Secondly, we must formulate scheme to establish intermediaries of educational assessment related to "the Belt and Road" to ensure the quality of Sino-foreign cooperation in running schools. Intermediaries of educational assessment should be supervised by NPC Education, Science, Culture and Public Health Committee.

The management innovation of Sino-foreign cooperation in running schools is the premise to promote "the Belt and Road" construction and the economic, social and scientific development. Through training talents for special demands, "output" Sino-foreign cooperation in running schools, bringing in and dispatching more overseas students, we can continuously strengthen the management innovation of Sinoforeign cooperation in running schools, integrate Sinoforeign cooperation in running schools with "the Belt and Road" strategy and give play to its functions in training international talents, spreading Chinese culture and expanding influence of Chinese universities, at the meantime, make Sino-foreign cooperation in running schools develop ceaselessly in serving "the Belt and Road" strategy.

\section{CONCLUSION}

To sum up, the management innovation of Sino-foreign cooperation in running schools is the premise to promote "the Belt and Road" construction and the economic, social and scientific development. Under the background of "the Belt and Road" strategy, managers of Sino-foreign cooperation in running schools must meet requirements of national key strategies, update ideas and seize opportunities as well as face new challenges, realize the acceleration of "the Belt and Road" strategy for Sino-foreign cooperation in running schools. According to the existing problems in Sinoforeign cooperation in running schools, through training talents for special demands, "output" Sino-foreign cooperation in running schools, bringing in and dispatching more overseas students, we can continuously strengthen the management innovation of Sino-foreign cooperation in running schools, integrate Sino-foreign cooperation in running schools with "the Belt and Road" strategy and give play to its functions in training international talents, spreading Chinese culture and expanding influence of Chinese universities, at the meantime, make Sino-foreign cooperation in running schools develop ceaselessly in serving "the Belt and Road" strategy.

\section{REFERENCES}

[1] "Xi Jinping Makes an Important Speech at Nazarbayev University in Kazakhstan: Carry forward Friendship between People, Create a Better Future Together", people.com.cn, Sept.7, 2013, refer to http://cpc.people.com.cn/n/2013/0907/c64094-22841981.html

[2] "Xi Jinping Deliver a Speech at Parlemen Indonesia: Join Hands to Construct China-ASEAN Community of Common Destiny", people.com.cn, Oct.3, 2013, refer to http://politics.people.com.cn/n/2013/1003/c1024-23101457.html.

[3] "CCTV Issue Authoritative "the Belt and Road" Domain (Picture) NetEase News website, Apr.14, 2015, refer to http://news.163.com/15/0414/06/AN5490VE0001124J.html?bdsj.

[4] Regulations of the People's Republic of China on Chinese-Foreign Cooperation in Running Schools, Decree No. 372 of the State Council of the People's Republic of China on March 1, 2003

[5] LYNCH K. Neo-liberalism and Mercerization: the Implication for Higher Education [J]. European Education Research Journal, 2006, (1):1-17.

[6] Altbach, P.G. \& Knight, J. The Internationalization of Higher Education: Motivations and Realities [J]. Journal of Studies in International Education, 2007, (11)

[7] Zhao Yanzhi, Ge Tingting. Characteristics of Sino-foreign Cooperation in Running School and Development Paths [J], Chinese Higher Education, 2014 (20): 54-56

[8] Li Qing, Han Huixiao. Establishment of Supervision System of Sinoforeign Cooperation in Running School [J], Supervision of Managers, 2015 (35): 282

[9] Fan Zengguang, Shi Wanbing. Historical Evolution of Quality Guarantee System of British Higher Education and Experience Reference [J], Journal of Northeastern University (Social Science); 2014 (6): 635-639

[10] Information Platform for Supervision of Sino-foreign Cooperation in Running School of the People's Republic of China http://www.crs.jsj.edu.cn/index.php/default/index

[11] He Wanguo, Cai Zongmo, Yang Zhengqiang. Research on Countermeasures for Classification Development of Chinese Universities [J], China Higher Education Research, 2016 (2): 60-66

[12] Sun Ke. Promote Students' Deep Learning through International View-Discussion on Teaching Construction in Higher Level Sinoforeign Cooperative University [J], Journal of World Education, 2015 (2): 59-62

[13] Wang Yanxin. "The Belt and Road" Strategy Leads Internationalization of Higher Education [J], Guangming Daily, 2015(13): 1-2

[14] Jiang Yanqiao. Thinking on Key Problems of Sino-foreign Cooperation in Running School [J], Chinese Higher Education, 2012 (10): 13-14. 